\title{
Challenges and potentials of the production of comprehensive care in Primary Health Care in Brazil
}

\author{
Desafios e potencialidades para produção do cuidado integral na Atenção Primária à Saúde brasileira \\ Desafíos y potencialidades para producción del cuidado integrado en la Atención Primaria de Salud brasileña
}

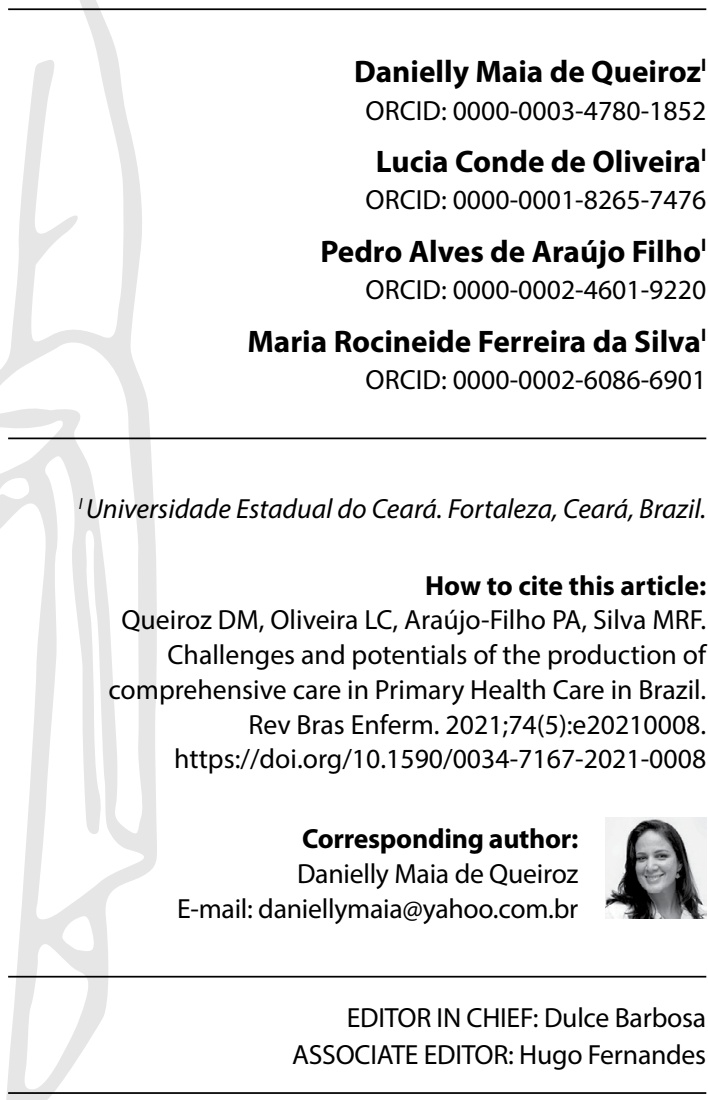

Submission: 01-07-2021
Approval: 04-02-2021

\begin{abstract}
Objective: To identify relational and organizational barriers related to the production of care and to map strategies and tools that favor comprehensive care. Methods: Scoping review of Brazilian publications from 2008 to 2018, related to the production of care in Primary Health Care. From the 348 studies found in the Virtual Health Library, 30 made up the final sample. Three book chapters were added, totaling 33 documents. Results: Three thematic categories were organized: Relational dimension between health professionals and users; Interactive dimension of the teamwork process; Organizational dimension and articulation in networks. Challenges of health practices out of context of the users'needs; inflexible and bureaucratic work processes; and organizational barriers to the access are highlighted. The potentials of mapped tools involved embracement, interprofessional actions and instituting care networks. Final considerations: The overview of challenges and processes that induce good practices facilitate a decision-making that is committed with comprehensive care. Descriptors: Primary Health Care; Comprehensive Health Care; Patient Care Team; Public Health Practice; Public Health Policy.
\end{abstract}

\section{RESUMO}

Objetivo: Identificar entraves relacionais e organizacionais relativos à produção do cuidado e mapear estratégias e dispositivos favoráveis ao cuidado integral. Métodos: Scoping review de publicações brasileiras de 2008 a 2018, relacionadas à produção do cuidado na Atenção Primária à Saúde. Dos 348 estudos encontrados na Biblioteca Virtual da Saúde, 30 compuseram a amostra final, sendo acrescidos três capítulos de livro, totalizando 33 documentos. Resultados: Organizaram-se três eixos temáticos: Dimensão relacional entre profissionais de saúde e usuários; Dimensão interativa do processo de trabalho em equipe; e Dimensão organizacional e articulação em redes. Destacam-se desafios de práticas de saúde descontextualizadas das necessidades dos usuários; processos de trabalho cristalizados e burocratizados; e entraves organizacionais de barreiras de acesso. Potencialidades de dispositivos mapeados envolveram acolhimento, ferramentas de interprofissionalidade e redes instituintes de cuidado. Considerações finais: A panorâmica de desafios e processos indutores de boas práticas facilitam tomada de decisões comprometidas com um cuidado integral.

Descritores: Atenção Primária à Saúde; Assistência Integral à Saúde; Equipe de Assistência ao Paciente; Prática de Saúde Pública; Políticas Públicas de Saúde.

\section{RESUMEN}

Objetivo: Identificar bloqueos relacionales y organizacionales relativos a producción del cuidado y mapear estrategias y dispositivos favorables al cuidado integral. Métodos: Scoping Review de publicaciones brasileñas de 2008 a 2018, relacionadas a producción del cuidado en Atención Primaria de Salud. De 348 estudios encontrados en la Biblioteca Virtual de Salud, 30 comprendieron la muestra final, siendo acrecidos tres capítulos de libro, totalizando 33 documentos. Resultados: Organizaron tres ejes temáticos: Dimensión relacional entre profesionales de salud y usuarios; Dimensión interactiva del proceso laboral en equipo; y Dimensión organizacional y articulación en redes. Destacan desafíos de prácticas de salud descontextualizadas de las necesidades de los usuarios; procesos de trabajo cristalizados y burocratizados; $y$ bloqueos organizacionales de barreras de acceso. Potencialidades de dispositivos mapeados envolvieron recepción, herramientas interprofesionales y redes instituyentes de cuidado. Consideraciones finales: Panorámica de desafíos y procesos inductores de buenas prácticas facilitan toma de decisiones comprometidas con un cuidado integral.

Descriptores: Atención Primaria de Salud; Atención Integral de Salud; Grupo de Atención al Paciente; Práctica de Salud Pública; Políticas Públicas de Salud. 


\section{INTRODUCTION}

The production of care presupposes dialogical meetings, and the establishment of subjective relationships between users and health professionals that start from the mutual recognition of knowledge, expectations, and desires. These are influenced by the setting and by the degree of suffering and clinical instability involved, since there are very different types of care in health. While some produce tutoring and subjection, others strengthen the subjects' powers to face life, promoting autonomy ${ }^{(1)}$. The search for integrality values the needs of the subjects, making the production of care more complex, since it requires a work process that integrates the knowledge and actions of different professions and actions in care of the users themselves ${ }^{(2)}$.

From the perspective of producing subjectivities, the production of care is guided by ethical precepts that reorganize the decision-making processes of practices in the daily life of services, considering the needs of users in a negotiated and inclusive way, as well as the articulation of knowledge for the active learning of relational and interactional dynamics ${ }^{(3)}$.

The health worker, when producing care, turns himself into a subject of the action and recognizes the user as a subject too, both increasing knowledge through their encounter ${ }^{(4)}$. Certainly, when health professionals commit to the production of other existential territories, allowing themselves to be affected and perceiving the multiplicity of recognizing potential life in the other, the bonds and co-responsibility can be strengthened, to the detriment of "iatrogenesis, interdictions, atrocities and everyday microviolences" ${ }^{\prime \prime(5)}(p .404)$.

Understanding the interdependence of the other in exchange relations implies recognizing users as autonomous subjects, producers of care and not merely consumers of services. Consequently, this system of interpersonal exchanges involves the reciprocity of the movements of giving, receiving, and giving back. They interact in multiple perspectives, from sensitive approaches to necessary distances, constituting a setting for the production of spaces for protagonism and care ${ }^{(6)}$.

Thus, the discussion on health care involves multiple references from different currents of thought, such as Merhy ${ }^{(7)}$ and his studies on the micropolitics of alive work in action and health technologies; Campos ${ }^{(8)}$, with Saúde Paideia, and the expanded and shared clinic; Ayres ${ }^{(9)}$, with the processes of subjectification in health practices that imply quality and respect for the other; and Pinheiro and Mattos ${ }^{(10)}$, with the multiple meanings of integrality that comprise the acts of care in health care.

Considering these assumptions, the desired change in the model of care, committed to the production of comprehensive care, requires an inversion of technological rationality that guides the knowledge and practices in health production to a work process centered on soft and soft-hard technologies ${ }^{(7)}$. These are materialized in relational practices, in dialogue, in respect for others, in qualified listening, in the sharing and co-responsibility of care. The result of this change consists of the so-called expanded $\operatorname{clini}^{(8)}$, centered around the user, their needs, subjectivation processes and projects to generate satisfaction ${ }^{(9)}$.

Therefore, among the various settings that make up the care networks of the Unified Health System (SUS), Primary Health Care
(PHC) is a privileged and well-connected locus that affects the process of reorienting the assistance in health, where the valorization of relational technologies and the investment in expanded and shared clinics can add quality to the work process, mobilizing the conditions for the realization of comprehensive care. It is worth mentioning that, in the Brazilian context, the Family Health Strategy (FHS) started to be adopted as a structuring model of PHC for the reorientation of knowledge and practices that guide health care ${ }^{(11)}$.

However, even recognizing the PHC context as a fertile territory for a construction shared between users and health professionals, a powerful place for the recognition of life-producing relationships in the territory, and a place of strengthening bonds and relationships of trust, it has been admitted, in recent years, that there has been a tendency for these "meetings" to become less relevant. This is due to factors such as the overload of the teams, the rise of a managerialist perspective that invests in the control of the time and movements of the team instead of favoring an open and productive encounter, and the instrumental perspective about the territory and users, with the intention of governing their lives ${ }^{(1)}$.

To make matters more complex, the approval of Constitutional Amendment 95/2016 ${ }^{(12)}$ came into play. This piece of legislation restricts the budget and freezes public spending on health, social assistance, and education for 20 years. This is a recognizable and clear threat to SUS and its entire network of actions and services made into an integrated public policy ${ }^{(13)}$, capable of involving subjects who are ethically and politically committed to the production of comprehensive quality care.

Furthermore, the changes in the financial organization of SUS and the changes made to the National Primary Care Policy $\mathrm{PNAB}^{(14)}$ opened spaces for the logic of a selective and fragmented PHC, with repercussions on the model of care and management of health work. Some of its criticized aspects referred to the flexibility of the composition of the team and the workload, the changes in the attributions of the community health agents and the return of funding of traditional medical-centered primary care teams $\mathrm{s}^{(15)}$, in addition to the end of the stimulus to the formation of multidisciplinary teams.

These austerity measures and normative changes occurred even in the face of scientific evidence that indicates the importance of social protection policies to face the crises of capitalism ${ }^{(16)}$, and despite the fact that the health situation and the access of the population to health services have improved in the these more than 30 years of SUS. Also, there are countless challenges for the achievement of the right to public, universal, and integral health in a continental and populous country ${ }^{(17)}$.

The synthesis of some of this evidence can be seen in reviews by Arantes, Shimizu and Merchán-Hamann ${ }^{(18)}$ on the contributions and challenges of the FHS as a model of care; and in the analyses by de Menezes et al. ${ }^{(19)}$ on how Brazilian PHC professionals contribute to universal access to health services. It also can be seen in the study of Santos, Mishima and Merhy ${ }^{(20)}$ on the potential of the work process in the FHS for the reconfiguration of the care model, by highlighting that the production of care based on the concept of integrality would be committed to health practices directed to the objective needs and subjective situations of people in their social context, apprehended and transformed into actions by a multidisciplinary team. 
Given the above, the question is: What is the scientific evidence regarding the challenges and potential of the process of producing comprehensive care in the context of Primary Health Care in Brazil?

At first, the relational and organizational barriers that were highlighted in the studies which made up the corpus of this scope review were synthesized and expressed as disagreements between the subjects, resistances to collaborative work and access barriers. Then, an attempt was made to integrate the mapping of strategies and tools that favor a comprehensive care, providing concrete and successful responses and promoting meaningful intersubjective encounters, openness to change, and effective network flows.

\section{OBJECTIVE}

To identify scientific evidence on relational and organizational barriers related to the production of care and to map strategies and tools that favor comprehensive care.

\section{MATERIALS AND METHOD}

This is a scoping review ${ }^{(21)}$, in which the instrument Preferred Reporting Items for Systematic reviews and Meta-Analyzes extension for Scoping Reviews (PRISMA-ScR) ${ }^{(22)}$ was used to facilitate the organization and development. According to Munn et al. ${ }^{(23)}$, the reasons for developing a scope review are, among others, to identify the types of evidence available and the knowledge gaps in a given theme; to clarify key concepts and definitions in literature; and to identify main characteristics or factors related to a concept.

To elaborate the research question, the strategy described by the mnemonic PCC - Population, Concept and Context - was adopted. This strategy was adapted to contemplate the objective of the review, where $P$ was empirical research and theoretical essays published in Brazilian journals; $C$ was challenges and potential of the comprehensive care production process; and C was Primary Health Care that constitutes the Primary Care of SUS.

The eligibility criteria consisted of scientific productions published in Brazilian journals that presented: challenging situations and obstacles in the relational or organizational context that interfered in the way in which the meeting between health professionals and users occurs; strategies or tools that enhance the care production process in the PHC services of the SUS care network in alignment with the premise of comprehensiveness.

A survey of scientific productions made available at the Virtual Health Library (BVS) was carried out between February and April 2020, using the key expression "care production" as a search strategy. Then, the following filters available in the database were used: full text, available in Brazilian Portuguese, published between 2008 and 2018. The choice of the Brazilian Portuguese language was justified by the authors' interest in publications of Brazilian journals. The ten-year interval considered the stage of expansion and consolidation of the FHS in the national territory, and the period in which it was sought to expand PHC's problem-solving capabilities with the creation of the Family Health Support Team (NASF).

For the eligibility process, the authors decided to include scientific articles from empirical research, theoretical essays, experience reports and reviews that contained as main subject the themes: "Primary Health Care", "Family health", "Family Health Strategy" or "comprehensive health care". Publications in the form of theses and dissertations, normative documents, repeated articles, or articles that did not contemplate the context of PHC were excluded.

In the initial study selection process, a total of 348 productions was found. Then, by reading the titles, 93 studies were considered eligible for reading the abstracts. At the end of this stage, 38 articles were selected to be read in full. Among these, 30 articles covered the guiding question and were selected to compose the process of analysis and synthesis of the results. In addition, three chapters of the collection entitled"Shared evaluation of health care: surprising what was instituted in the networks" were added, as they included important theoretical and practical reflections on tools linked to the production of comprehensive care in their discussions.

As a result, the final sample included a total of 33 documents that made up the corpus of the review, with 30 scientific articles and three book chapters available on a digital platform. The search and selection process of the studies is systematized in the flowchart of Figure 1, according to the recommendations of the Joanna Briggs Institute ${ }^{(22)}$, following the instructions of PRISMA-ScR.

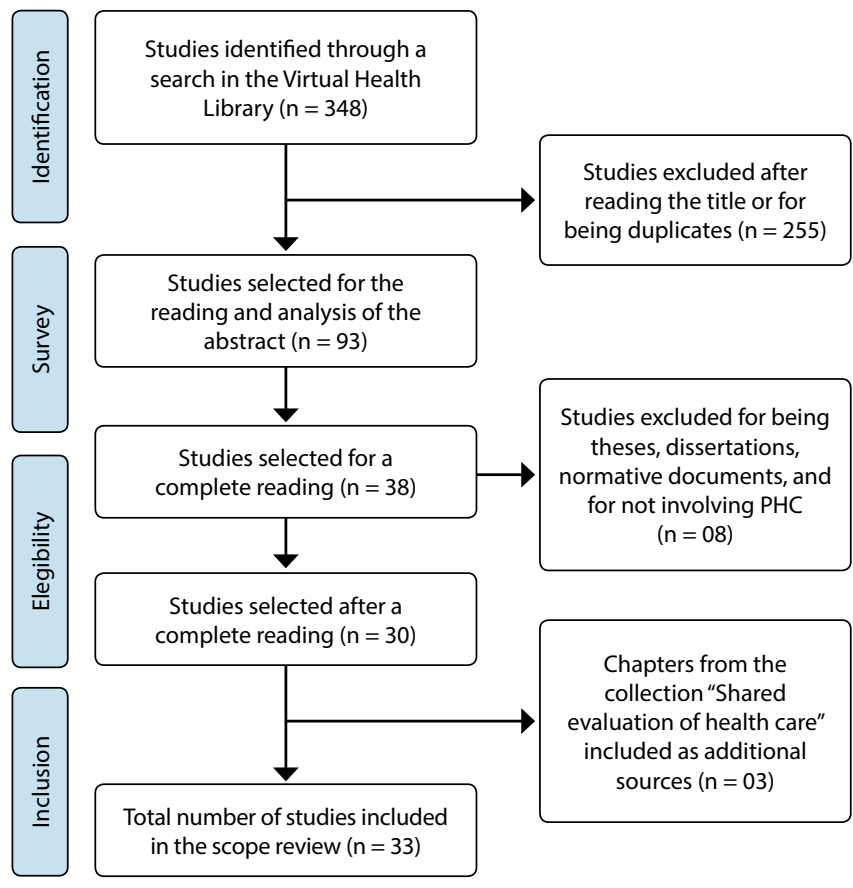

Figure 1 - Flowchart of the study selection process adapted from PRISMA ${ }^{(22)}$

The extraction of data from the articles was organized based on the elaboration of an instrument that contained the following items: title, authors, year of publication, journal or collection and type of study; and also challenges and obstacles, strategies and tools. The studies included in the scope review were listed in Table 1, with their respective codifications, titles, authorship, year of publication, sources, and types of study. Each study received a codification (E1, E2 ... E33), organized in chronological order of publication.

The data related directly to the guiding question were organized and summarized in three thematic axes, namely: I) Relational dimension between health professionals and users: meetings and mismatches; II) Interactive dimension of the teamwork process: openings and resistances; and III) Organizational dimension and articulation in networks: flow and barriers to access. In the analysis 
process, the theoretical contributions of light technologies ${ }^{(7)}$, expanded and shared clinic $^{(8)}$ and intersubjective meetings related to health practices ${ }^{(9)}$ contributed to the conceptual mapping and the combination of the results obtained.

\section{RESULTS}

The 33 selected studies were published from 2008 to 2018. Among them, 24 were original articles of empirical research (E1,
E3, E5, E6, E7, E9, E11, E12, E13, E14, E16, E18, E19, E21, E22, E23, $E 24, E 25, E 26, E 27, E 28, E 30, E 31, E 32), 4$ were theoretical essays $(E 2, E 10, E 29, E 33), 3$ were experience reports (E4, E15, E17), and 2 were reviews (E8, E20).

Of the 30 selected articles, 23 were published in public health journals (E1, E2, E3, E4, E5, E6, E8, E9, E10, E11, E12, E15, E16, E17, $E 18, E 19, E 20, E 23, E 26, E 28, E 31, E 32, E 33), 5$ in nursing journals (E7, E14, E25, E27, E30), 1 in an odontology journal (E29), and 1 in the multidisciplinary health journal (E13).

Chart 1 - Studies related to the production of care, distributed by title, authors, year of publication, Journal/collection and type of study

\begin{tabular}{|c|c|c|c|c|}
\hline TITLE & AUTHORS & YEAR & SOURCES & TYPES OF STUDY \\
\hline $\begin{array}{l}\text { E1. Social representation related to care in the family health program in } \\
\text { Natal-Brazil(24) }\end{array}$ & $\begin{array}{l}\text { Rodrigues; Lima; } \\
\quad \text { Roncalli }\end{array}$ & 2008 & $\begin{array}{l}\text { Ciência e Saúde } \\
\text { Coletiva }\end{array}$ & Empirical research \\
\hline $\begin{array}{l}\text { E2. Collectives arranged to produce integral care: a challenge to professional } \\
\text { regulation }{ }^{(2)}\end{array}$ & Cavalcante-Filho & 2009 & Revista de APS & Theoretical essay \\
\hline $\begin{array}{l}\text { E3. The work process in health and the production of care in a Family Health } \\
\text { Unit: limits to the reception and reflections on the emergency service }{ }^{(25)}\end{array}$ & Barros; Sá & 2010 & $\begin{array}{l}\text { Ciência e Saúde } \\
\text { Coletiva }\end{array}$ & Empirical research \\
\hline E4. Care production and pedagogical production in participatory planning ${ }^{(26)}$ & Franco; Koifman & 2010 & Interface (Botucatu) & Experience report \\
\hline $\begin{array}{l}\text { E5. Production of comprehensive prenatal care: a pregnant woman's route at } \\
\text { a primary family healthcare unit }{ }^{(27)}\end{array}$ & Albuquerque et al. & 2011 & Interface (Botucatu) & Empirical research \\
\hline $\begin{array}{l}\text { E6. Healthcare regulation and healthcare management as tools to assure } \\
\text { comprehensiveness and equity in health }{ }^{(28)}\end{array}$ & Baduy et al. & 2011 & $\begin{array}{l}\text { Cadernos de Saúde } \\
\text { Pública }\end{array}$ & Empirical research \\
\hline E7. Saúde da família: visão dos usuários ${ }^{(29)}$ & Nery et al. & 2011 & $\begin{array}{l}\text { Revista de Enfermagem } \\
\text { da UERJ }\end{array}$ & Empirical research \\
\hline $\begin{array}{l}\text { E8. The relationship between healthcare personnel and patients (user } \\
\text { acceptance) regarding the family healthcare program: a review of } \\
\text { approaches in Brazilian journals }{ }^{(30)}\end{array}$ & $\begin{array}{l}\text { Vieira-dos-Santos; } \\
\quad \text { Santos }\end{array}$ & 2011 & Revista de Salud Pública & Systematic review \\
\hline $\begin{array}{l}\text { E9. The Interlocution of Mental Health with Primary Care in the City of Vitoria } \\
-\mathrm{ES}^{(31)}\end{array}$ & Rodrigues; Moreira & 2012 & Saúde e Sociedade & Empirical research \\
\hline $\begin{array}{l}\text { E10. Cooperação interprofissional e a Reforma Sanitária no Brasil: } \\
\text { implicações para o modelo de atenção à saúde e }{ }^{(3)}\end{array}$ & $\begin{array}{l}\text { Matuda; Aguiar; } \\
\text { Frazão }\end{array}$ & 2013 & Saúde e Sociedade & Theoretical essay \\
\hline $\begin{array}{l}\text { E11. Link and responsibility as ways to provide care in family's health } \\
\text { strategy }\end{array}$ & $\begin{array}{l}\text { Amorim; Assis; } \\
\text { Santos }\end{array}$ & 2014 & $\begin{array}{l}\text { Revista Baiana de Saúde } \\
\text { Pública }\end{array}$ & Empirical research \\
\hline E12. Lay agency and healthcare: producing healthcare maps ${ }^{(33)}$ & Cecílio et al. & 2014 & $\begin{array}{l}\text { Cadernos de Saúde } \\
\text { Pública }\end{array}$ & Empirical research \\
\hline $\begin{array}{l}\text { E13. Health needs and production of care in a health unit in a city of the } \\
\text { northeast part of Brazil( }{ }^{(34)}\end{array}$ & Souza et al. & 2014 & O mundo da saúde & Empirical research \\
\hline $\begin{array}{l}\text { E14. Matrix support, individual therapeutic project and production in mental } \\
\text { health care }{ }^{(35)}\end{array}$ & Jorge et al. & 2015 & $\begin{array}{l}\text { Texto \& Contexto } \\
\text { Enfermagem }\end{array}$ & Empirical research \\
\hline $\begin{array}{l}\text { E15. Institutional support in primary health care: the experience in Salvador } \\
- \text { BA }^{(36)}\end{array}$ & Machado; Mattos & 2015 & $\begin{array}{l}\text { Revista Baiana de Saúde } \\
\text { Pública }\end{array}$ & Experience report \\
\hline $\begin{array}{l}\text { E16. Interprofessional collaboration in the Family Health Strategy: } \\
\text { implications for the provision of care and work management }{ }^{(37)}\end{array}$ & Matuda et al. & 2015 & $\begin{array}{l}\text { Ciência e Saúde } \\
\text { Coletiva }\end{array}$ & Empirical research \\
\hline E17. No beginning and no end ... with body practices and Expanded Clinics ${ }^{(38)}$ & Mendes; Carvalho & 2015 & Interface (Botucatu) & Experience report \\
\hline $\begin{array}{l}\text { E18. Production of care in Brazil's Family Health Strategy: the challenges of } \\
\text { work management and continuing health education }{ }^{(4)}\end{array}$ & Santos et al. & 2015 & Revista de APS & Empirical research \\
\hline $\begin{array}{l}\text { E19. About the reception: discourse and practice in the Basic Health Units in } \\
\text { the city of Rio de Janeiro }{ }^{(39)}\end{array}$ & Silva; Romano & 2015 & Saúde em Debate & Empirical research \\
\hline $\begin{array}{l}\text { E20. The benefits and challenges of the Family Health Strategy in Brazilian } \\
\text { Primary Health care: a literature review }{ }^{(18)}\end{array}$ & $\begin{array}{l}\text { Arantes; Shimizu; } \\
\text { Merchán-Hamann }\end{array}$ & 2016 & $\begin{array}{l}\text { Ciência e Saúde } \\
\text { Coletiva }\end{array}$ & Literature review \\
\hline $\begin{array}{l}\text { E21. Mas ele não adere! - o desafio de acolher o outro que é complexo para } \\
\operatorname{mim}^{(40)}\end{array}$ & Baduy et al. & 2016 & $\begin{array}{l}\text { Avaliação } \\
\text { compartilhada do } \\
\text { cuidado em saúde (V.1) }\end{array}$ & Empirical research \\
\hline $\begin{array}{l}\text { E22. Arranjos regulatórios como dispositivos para o cuidado compartilhado } \\
\text { em saúde }{ }^{(41)}\end{array}$ & Bertussi et al. & 2016 & $\begin{array}{l}\text { Avaliação } \\
\text { compartilhada do } \\
\text { cuidado em saúde (V.1) }\end{array}$ & Empirical research \\
\hline
\end{tabular}




\begin{tabular}{|c|c|c|c|c|}
\hline TITLE & AUTHORS & YEAR & SOURCES & TYPES OF STUDY \\
\hline $\begin{array}{l}\text { E23. Micro-regulatory processes in a Primary Health Care Service and the } \\
\text { production of health care }{ }^{(42)}\end{array}$ & Oliveira et al. & 2016 & Saúde em Debate & Empirical research \\
\hline $\begin{array}{l}\text { E24. Vínculo e responsabilização: Como estamos engravidando esses } \\
\text { conceitos na produção do cuidado na Atenção Básica? }\end{array}$ & Seixas et al. & 2016 & $\begin{array}{c}\text { Avaliação } \\
\text { compartilhada do } \\
\text { cuidado em saúde (V.1) }\end{array}$ & Empirical research \\
\hline $\begin{array}{l}\text { E25. Mental health care in the family health strategy: the experience of } \\
\text { matrix support }{ }^{(43)}\end{array}$ & Gurgel et al. & 2017 & $\begin{array}{l}\text { Revista de Enfermagem } \\
\text { da UERJ }\end{array}$ & Empirical research \\
\hline $\begin{array}{l}\text { E26. Professionals as network producers: compositions and connections in } \\
\text { health care }{ }^{(44)}\end{array}$ & Maximino et al. & 2017 & Saúde e Sociedade & Empirical research \\
\hline $\begin{array}{l}\text { E27. Production of care for resolubility of the Family Health Strategy: } \\
\text { knowledge and dilemmas }{ }^{(45)}\end{array}$ & Rios; Nascimento & 2017 & $\begin{array}{l}\text { Revista de Enfermagem } \\
\text { UFPE Online }\end{array}$ & Empirical research \\
\hline $\begin{array}{l}\text { E28. Perceptions of users about humanization in family health strategy: a } \\
\text { study based on the Theory of } \mathrm{Gift}^{(6)}\end{array}$ & Cunha et al. & 2017 & Ciência Plural & Empirical research \\
\hline $\begin{array}{l}\text { E29. Health care production focused on the Expanded Clinic: a necessary } \\
\text { debate in dental education }{ }^{(46)}\end{array}$ & Graff; Toassi & 2017 & Revista ABENO & Theoretical essay \\
\hline E30. The production of care in the routine of Family Health Teams ${ }^{(47)}$ & Agonigi et al. & 2018 & $\begin{array}{l}\text { Revista Brasileira de } \\
\text { Enfermagem }\end{array}$ & Empirical research \\
\hline E31. Redesigning pathways towards the expanded oral health clinic ${ }^{(48)}$ & Fonsêca et al. & 2018 & Saúde e Sociedade & Empirical research \\
\hline $\begin{array}{l}\text { E32. Oral health clinic as a space for the production dialogue, connection } \\
\text { and subjectivity among users and dentists of Primary Care }\end{array}$ & Graff; Toassi & 2018 & $\begin{array}{l}\text { Physis - Revista de } \\
\text { Saúde Coletiva }\end{array}$ & Empirical research \\
\hline $\begin{array}{l}\text { E33. User embracement as a surveillance strategy in health care production: } \\
\text { an epistemological reflection }{ }^{(50)}\end{array}$ & Silva et al. & 2018 & Saúde em Debate & Theoretical essay \\
\hline
\end{tabular}

Taking into account the thematic categories listed to facilitate the organization and synthesis of evidence, considering the "Relational dimension between health professionals and users", aspects that favor intersubjective meetings (E1, E2, E3, E5, E7, E8, E11, E20, E24, E26, E27, E28, E29, E30, E31, E32, E33) and mismatches between subjects (E2, E3, E5, E6, E18, E19, E24, E26) were found. Regarding the "Interactive dimension of the teamwork process", openings (E2, $\mathrm{E6}, \mathrm{E} 10, \mathrm{E} 13, \mathrm{E} 11, \mathrm{E} 16, \mathrm{E} 17, \mathrm{E} 18, \mathrm{E} 23, \mathrm{E} 25, \mathrm{E} 28, \mathrm{E} 33)$ and resistance to interprofessional collaboration (E2, E8, E9, E11, E16, E20, E21, E25, E29) were identified. In the "Organizational dimension and articulation in networks", favorable flows (E4, E12, E16, E22, E26, E30, E31) and access barriers (E6, E8, E12, E13, E14, E15, E20, E27, E28) were mapped.

\section{DISCUSSION}

\section{Relational dimension between health professionals and users: meetings and mismatches}

The work process and the production of care in the hegemonic health care model are health practices that are not centered on the users'singular needs or on the resolution of their demands at a specific time ${ }^{(28)}$. The time is linked to subjective criteria based on the user's suffering during their search for health care and to the predominant mode of subjectivation and sociability in contemporary times ${ }^{(25)}$.

In the context of PHC, welcoming the user with qualified listening as a care technology is a potential tool for consolidating comprehensiveness. Based on relational technologies, it mobilizes the sensitivity, reflective action, and an ethical stance of health workers permeable to active listening and dialogue. This welcoming is fundamental to guarantee accessibility and the establishment of a trusting relationship between health professional and user, which allows the manifestation of the subjectivity of the other through a communicational process of qualified listening and adequate responses to the identified demands. This has the potential for strengthening interpersonal bonds, reorienting health practices, and producing comprehensive care, based on co-responsibility, respect and human dignity ${ }^{(2,24,27,29-30,32,46,50)}$.

Still, in this intense and complex intersubjective situation, the different institutional regimes and the existence of complex cases directly affect the possibilities of care production ${ }^{(44)}$. When faced with challenging cases of resistant users and who do not adhere to the therapeutic plan unilaterally designed by those who believe they know "what is the best"for them, health professionals can renounce the ideal type of submissive users and experience a shared and co-responsible care process. This often leads to discomfort and inconveniences those who insist on operating in a protocolar logic and in the attempt to control the situations. However, it is in this resistance of the users that the expression of their power and the desire to keep control over themselves can be found, not to mention it can be possible for health professionals to go into a process of leaving their comfort zone and reframing their way of producing care ${ }^{(5,40)}$.

In this sense, a production of care based on dialogue, on respectful, welcoming and resolutive professional performance, provides the strengthening of bonds of trust ${ }^{(25,45)}$, enabling an expanded approach to health, contextualized with the territory and its social determinants ${ }^{(46)}$. From the perspective of the expanded clinic, it fosters greater diagnostic capabilities and the effectiveness of the therapeutic act ${ }^{(24)}$. However, health professionals often perceive embracement as a relational technology, but in practice, what is evident in several settings, is that users endure a veritable pilgrimage in search of care and there is a fragile teamwork in the welcoming design proposed by the service ${ }^{(39)}$.

In addition, sometimes listening is limited to complaints, due to the high demand for activities, weakening the bond between professionals and users. In this complaint-conduct logic, prescriptions and standards provide little space for the creativity and autonomy 
of subjects ${ }^{(4)}$. Even the accumulation of knowledge and experience of community health agents, in relation to the community context and the conditions of risk and vulnerabilities of the territory covered by the team, are little valued, and all of this ends up negatively impacting the care production processes ${ }^{(25)}$. What predominates in the daily routine of services are bureaucratic relations from the reception to consultations or making referrals ${ }^{(27)}$.

This review found that the breadth of actions that seek to address the entire life cycle, longer professional experience, a reception with qualified listening, the mediation of community health agents, and home visits that bring teams closer to the community context and family dynamics, are aspects that favor and strengthen the bond between the teams and the people under their responsibility ${ }^{(6,18)}$. This is how relationships of affection and trust between workers and users are constructed ${ }^{(5-6)}$.

It is noteworthy that a bond presupposes a relationship. Therefore, it is not possible to build it unilaterally. For this particular relationship to be strengthened, there must be a mutual recognition of "valid interlocutors". It is an ethical posture that makes it possible to agree and accept needs, desires and expectations that are different between the subjects, since in these intervening meetings, processes of deterritorialization unfold ${ }^{(5,44)}$.

Thus, the production of symmetrical relationships capable of generating bonding and accountability makes it possible to face a tendency to rival these notions, which, in addition to producing more barriers than inclusion, still acts in the production of subjectivity that generates "blaming" the user instead of accepting their demands, needs and desires ${ }^{(5)}$. As a result, it is necessary to question how these relations are being established in daily work, reflecting on the extent to which teams trust users and value their voice, thus understanding the production of care as a relationship to be buil(t4).

When health professionals use creativity and innovation to share the therapeutic plan with users, it is possible to enrich the dialogue and expand the autonomy of the subjects involved. These initiatives, although seemingly strange, are innovative practices in the production of care and are based on relational technologies, expanded clinic and on a person-centered approach ${ }^{(46-49)}$.

\section{Interactive dimensions of the teamwork process: openings and resistances}

The work process centered on clinical and prescriptive acts leads to a model that is not very capable of problem solving, in which individualized professional postures ${ }^{(30)}$ and health practices establish cold, bureaucratic, impoverished relationships ${ }^{(31)}$ and are decontextualized from the needs and particularities of the problems presented by users. This work process is commonly criticized by users, managers and the health workers themselves ${ }^{(32)}$, resulting in a production of care that is not compromised with life and with the constitution of active subjects ${ }^{(43)}$.

In this context, a good reception of the patient is the first step in the internal micro-regulation process of a health unit ${ }^{(50)}$, as a mechanism for inclusion and attention to spontaneous demand with qualified listening ${ }^{(42)}$. It is an element for assessing the quality of the health service, capable of triggering reflections and changes in the organization of the work process, either by altering flows or enhancing teamwork, enabling an alignment between users' health needs and the capacities the service has to solve problems and show more accountability ${ }^{(34)}$.

In addition, when the focus of care is shifted towards the production of procedures, there is a risk of reproducing biomedical rationality in the work process ${ }^{(40)}$, which is often supported by a market logic, where corporate disputes over the monopoly of diagnoses and prescriptions occur. Users are seen as consumers of health products and there is an incentive to fragment work in stages with little problem-solving capabilities ${ }^{(2)}$.

This situation is pointed out because of professional training in dissonance with a care model centered on PHC and the user, mainly focusing on technical procedures and fragmented health practices ${ }^{(18)}$, since the incorporation of relational technologies in clinical practice is still challenging and is in discussion in the field of health education ${ }^{(46)}$.

It has become evident that the negotiations established in these processes can reduce tensions and prioritize demands, making longitudinal care feasible, since the production of subjectivities in the territory allows for greater complicity between the community and the team ${ }^{(32)}$. Receiving the patient with qualified listening, affection, respect, honesty, quality of communication and dialogue are highlighted by users as indicators of humanized care $^{(6)}$. This implies in greater adherence by users to the care plan, because they feel safe and heard, due to the configuration of a network of responsibilities for the therapeutic projects built, in addition to work processes that excel by creativity and dialogue ${ }^{(4)}$.

This shared and co-responsible coordination to produce care is aligned with the perspective of "interprofessional collaboration", a term used to describe the interactive processes between professionals from different fields of knowledge, with participatory practices and strengthened interpersonal relationships. Such collaboration provides health care implied by comprehensive care and involves intensifying communication and shared decision-making ${ }^{(37)}$.

Inter-professional collaboration is considered a complex process, as it includes sharing, as the division of responsibilities and sharing of decisions; partnership, with the cultivation of relationships of affinity, open communication, mutual respect, and trust; interdependence, which requires the participation of each core of knowledge in therapeutic projects; and power, expressed as the empowerment of each member of the team, whose importance is recognized ${ }^{(3)}$.

The existence of tensions between traditional professional logic and collaborative practice presents itself as another challenge for comprehensive care. Professionals who operate in the traditional managerial logic of referral end up resorting to external services without first seeking the multiprofessional support team, in addition to focusing their practices on specialized procedures ${ }^{(37)}$. In some contexts, the act of meeting to discuss and get to know the cases better can be considered a "waste of time", whose apparatuses, such as support from central management, are delegitimized in the production of comprehensive care ${ }^{(31)}$.

In the context of the FHS, interprofessional collaboration between members of the reference teams and NASF teams can be achieved through support from central management, that is, technical, pedagogical, and care-related support received from a specialized team working in the back ranks of the operation. This organizational arrangement makes it possible to expand the clinic in a dialogical way, promoting the production of care 
through the discussion of cases and the shared, co-responsible and contextualized construction of singular therapeutic project (PTS), in a movement that breaks with traditional practices based on medicalization, referral and treatment and knowledge hierarchy ${ }^{(31,37)}$. Thus, central-management support enables the overcoming of a fragmented work logic that is still prevalent in the daily routine of services, and the user can count on the articulation of knowledge and actions capable of giving more resolute answers in face of their diverse demands to the service ${ }^{(43)}$.

Collaborative practices are intent on focusing on the health needs of the families and the community. However, they have to deal with the obstacle that is fulfilling the goals of producing consultations as required by management. This adds to the difficulty of working according to the difficulties of the reference teams and to clinical, epidemiological, and sanitary parameters found in the territory ${ }^{(37)}$. The team's planning process is also limited by the lack of records with useful information, the underutilization of available information systems, and the lack of monitoring ${ }^{(18)}$.

In this context, the groups organized as co-management, which are devices for organizing the work process and production of care, have the potential to induce more complex approaches to produce comprehensive care through meetings and exchanges, giving space to the alterity in the relationships established by the collective work. This configures "a teamwork that is necessarily co-managed, co-responsible and open to processes that institute new ways of producing $\operatorname{care}^{\prime \prime(2)}($ p.218), which operate according to ethical and political commitments to the defense of life, constituting spaces for problematization and agreement of work processes and production of comprehensive care ${ }^{(28)}$.

When teams recognize themselves as collectives that share responsibilities and practices, willing to discuss, plan and deliberate their actions in a more horizontal and dialogical way, teamwork is strengthened, allowing greater integration between the subjects. This becomes an interesting interprofessional process ${ }^{(37)}$, through which they articulate their knowledge and form a common field of work in health, with the appreciation of intersubjectivities and catalyzing different subjects' interests ${ }^{(32)}$, expanding the capacity to solve the problems in a contextualized and responsible way ${ }^{(4)}$.

Based on the premise that no single professional category has all the tools to provide comprehensive care, the practice of interprofessional collaboration requires willingness, flexibility, and openness from health professionals to put subjectively shared interests into action. The work becomes organized by the principle of shared responsibility for health between the reference team and the support team, favoring exchanges and expanded care ${ }^{(37,42)}$. Without disregarding the importance of clinical protocols in the organization or work processes, the determining criteria for the quality of the relationships produced in the meeting between health workers and users are openness to dialogue and the interest in building shared work ${ }^{(38)}$.

\section{Organizational dimension and network articulation: flow and barriers to access}

Disarticulation between services at different levels of care is an important challenge for comprehensive care, since it results in limited problem-solving capabilities, discontinuity of care, unaccountability, repeated work, and loss of quality of care provided to the user ${ }^{(28)}$.
The problems involved in the process of integrating the FHS into the care network are linked both to the insufficiency of specialized services that form long queues and to the communication difficulties between professionals in the network and even between members of the reference teams and NASF teams in the context of $\mathrm{PHC}^{(18)}$.

Users are often lost in the threads of health care networks, resorting to other forms of entry, such as urgent and emergency services, as a strategy for accessing the health system and solving their demands ${ }^{(6)}$. This is at the heart of the issue related to the valorization of these services by the users, despite the criticism made of the "complaintconduct" model, the lack of bond and empathy and the curative and fragmented approach that prevails at this point in the network ${ }^{(33)}$.

Recognizing that users compete for meanings and create loopholes in their"lay action", producing "care maps" and other possible arrangements of health systems and ways of thinking and organizing care, requires professionals to change their crystallized way of acting: it is necessary to brave other paths that take into account the real movement of users in search of care, well-being and mitigation of pain, once users are touched by suffering, illness and/or feelings of fragility, all of which are inherent to the human condition ${ }^{(33)}$.

It is interesting to note that users actively participate in the regulation of the system, even though they are not recognized and valued as a co-management strategy for care, since some managers and workers have difficulty in recognizing them as active producers. This is because they perceive services as "barrier producers", though some users create access possibilities and are not subordinate to the logic of a single form of assistance. Certainly, they will not stop looking for alternatives of bonding, of care, producing informal networks while the services offer options that involve the pilgrimage in an "analogue" network, since regulation only becomes meaningful in defense of life if it is worked to produce connections in networks based on shared care ${ }^{(41,44)}$.

Another example from a care network, identified in the publications, was provided by an experimentation with participatory planning, based on the premises of permanent health education and co-management, transforming relationships of intense conflict between health professionals and users into compromising devices of the community, as well as strengthening bonds and establishing co-responsibilities. Thus, "this whole process provided a change in attitude in the process of production of care and enhanced the development of the autonomy of the subjects involved"(26)(p.677).

With regard to the organizational barriers that affect the production of "carelessness", challenges were identified due to the little political autonomy of the FHS teams, the overvaluation of technicality and the distance from the theory to the real practice in health ${ }^{(45)}$. Supply and demand are disproportional, and there is a deficit in the technical composition of the work that burdens health professionals and an absence of planning centered on the needs of users and in the territorial context. These aspects contribute to the formation of repressed demands, to a crystallized work process and to fragmented care practices ${ }^{(18,34)}$.

Still, there are other limitations: inadequate infrastructure, restriction of supply inputs, obstacles in the adoption of embracement as a management device for organizing access and the work process, fragmented care focused on medicalization, problems in communication between workers, disarticulation between workers of different levels of attention and fragmentation 
of information systems ${ }^{(30)}$. Many services still maintain medicalcentered care standards, with excessive referrals and a PHC that depends on the support of specialized care ${ }^{(35)}$.

In the meantime, it has been highlighted that the discussion of cases and the joint construction of PTS as the guiding thread of the care production process expresses a resolutive work and, commonly, results in the satisfaction of both users and health work$\mathrm{ers}^{(37)}$. However, for this restructuring to take place in a fluid way in the daily life of the service, it is necessary to reorganize the work process of the teams and the joint programming of the activities agreed upon, demanding the construction of a shared agenda, aligned with the meeting spaces of the team. Such movement is not always easy to happen due to the resistance on the part of some professionals, a consequence of the lack of integration and coordination in the team ${ }^{(36)}$, as well as the way in which the services are organized, which may or may not favor these meetings.

The production of care mediated by light technologies allows the PTS to be proposed based on a mediation and negotiation with the user, requiring the displacement of prescriptive, imposing, and homogenizing actions, for the assumption of interactive, dialogical, and problem-solving postures, which take into account the needs of users and the specificities of the territory in which they operate ${ }^{(47)}$. Shared and particular therapeutic projects can be proposed through the exercise of an expanded clinic, and it is possible to find answers to the health needs of the subjects in a more assertive and problem-solving way ${ }^{(48)}$.

\section{Study limitations}

One of the limitations of this review is the restricted character of one of the eligibility criteria, since it included only national journals. Another limitation lies in the temporal dimension, which only included publications until 2018, a period that did not include more recent publications, which would express the unfolding of the socio-health crisis that is the COVID-19 pandemic, which directly affects the way in which care is provided in the PHC.

\section{Contributions to the area of Nursing, Health or Public Policies}

The panorama of challenges faced in the routine of $\mathrm{PHC}$ services and the processes that induce good practices represented by the strategies and tools that have been identified require greater investment from policies and decision makers, to facilitate ethically and politically compromised decisions with an integral care with problem-solving capabilities.
Furthermore, these processes are in dispute in the teams' daily work and in the way they relate to users who are monitored in health units, especially in the current context of systematic attempts to dismantle Brazilian public health policies.

\section{FINAL CONSIDERATIONS}

The production of care is linked to the micropolitics of the health work process, demanding collaborative integration committed to the production of shared and unique therapeutic plans and integral practices inside services or in the territory. Among the challenging situations identified, some stand out, including the health practices that do not consider the unique needs of users in a timely manner; the crystallized work processes focused on bureaucratic, medicalizing and procedural logic; and the obstacles related to the ways in which the services are organized, which end up producing barriers to access, establishing distant and noisy relationships between users, health professionals and managers.

In response to these challenges, strategies and devices that favor the production of comprehensive care were mapped, such as welcoming with qualified listening, the use of interprofessional tools and practices as conditions for collaborative teamwork, and the care networks coproduced by subjects. These devices have in common the openness of the subjects to active listening, the strengthening of intersubjective bonds, the valorization of existential territories and the collaborative work.

Therefore, the implementation of other ways of acting in health - centered around the needs and singularities of the subjects, guided by relational technologies and by the broad and shared clinical practices -, despite facing adversities and contradictory situations, many successful experiences have taken place in many varied contexts of Brazilian PHC, as could be evidenced in the publications that comprised this review. Thus, these good results have the potential for strengthening interpersonal bonds and reorienting the process of organizing health practices and producing comprehensive and contextualized care, based on co-responsibility, respect and human dignity.

\section{FUNDING}

Research for the SUS Program: shared management in health / PPSUS - CE (Edital 01/2017) - Fundação Cearense de Apoio ao Desenvolvimento Científico e Tecnológico, Secretaria Estadual de Saúde do Ceará/Ministério da Saúde, Conselho Nacional de Desenvolvimento Científico e Tecnológico (FUNCAP-SESA-Decit/ SCTIE/MS-CNPq).

\section{REFERENCES}

1. Feuerwerker LCM, Capozzolo AA. Atenção Básica e formação em saúde. In: Mendonça MHM, Matta GC, Gondim R, Giovanella L, (Orgs.). Atenção Primária à Saúde no Brasil: conceitos, práticas e pesquisa. Rio de Janeiro: Editora Fiocruz; 2018. p.291-310.

2. Cavalcante-Filho JB. Coletivos organizados para a produção do cuidado integral: um desafio para a regulamentação profissional. Rev APS [Internet]. 2009 [cited 2020 Jul 2];12(2):214-20. Available from: https://periodicos.ufjf.br/index.php/aps/article/view/14246

3. Matuda CG, Aguiar DML, Frazão P. Cooperação interprofissional e a Reforma Sanitária no Brasil: implicações para o modelo de atenção à saúde. Saúde Soc. 2013;22(1):173-86. https://doi.org/10.1590/S0104-12902013000100016 
4. Santos AM, Nóbrega IKS, Assis MMA, Jesus SR, Kochergin CN, Bispo-Jr JP, et al. Desafios à gestão do trabalho e educação permanente em saúde para a produção do cuidado na Estratégia Saúde da Família. Rev APS. 2015;18(1):39-49.

5. Seixas CT, Baduy RS, Bortoletto MSS, Lima JVC, Kulpa S, Lopes MLS, et al. Vínculo e responsabilização: como estamos engravidando esses conceitos na produção do cuidado na atenção básica? In: Feuerwerker LCM, Bertussi DC, Merhy EE, (Orgs.). Avaliação compartilhada do cuidado em saúde: surpreendendo o instituído nas redes. Rio de Janeiro: Hexis Editora; 2016. p.391-407.

6. Cunha ATR, Vilas RLA, Melo RHV, Silva AB, Rodrigues MP. Percepções de usuários sobre humanização na Estratégia Saúde da Família: um estudo ancorado na Teoria da Dádiva. Cienc Plural 2017;3(3):16-31. Available from: https://periodicos.ufrn.br/rcp/article/view/13094/9350

7. Merhy EE. Saúde: a cartografia do trabalho vivo. 4ed. São Paulo: Editora Hucitec; 2014. 187 p.

8. Campos GWS. Saúde Paidéia. 4ed. São Paulo: Editora Hucitec; 2015. 185 p.

9. Ayres JRCM. Sujeito, intersubjetividade e práticas de saúde. Cienc Saude Colet. 2001;6(1):63-72. https://doi.org/10.1590/ S1413-81232001000100005

10. Pinheiro R, Mattos RA, (Orgs.). Os sentidos da integralidade na atenção e no cuidado à saúde. 8ed. Rio de Janeiro: Editora UERJ, IMS, ABRASCO; 2009. $184 \mathrm{p}$.

11. Aquino R, Medina MG, Nunes CA, Sousa MF. Estratégia Saúde da Família e reordenamento do sistema de serviços de saúde. In: Paim JS, Almeida-Filho N, (Orgs.). Saúde Coletiva: teoria e prática. Rio de Janeiro: Editora Medbook; 2014. p.353-372.

12. Presidência da República (BR). Emenda Constitucional no 95, de 15 de dezembro de 2016. Altera o Ato das Disposições Constitucionais Transitórias para instituir o Novo Regime Fiscal e dá outras providências. Diário Oficial da União 2016; 15 de dezembro.

13. Facchini LA, Tomasi E, Dilélio AS. Quality of Primary Health Care in Brazil: advances, challenges and perspectives. Saúde Debate 2018;42(Esp):208-22. https://doi.org/10.1590/0103-11042018S114

14. Presidência da República (BR). Portaria MS n².436, de 21 de setembro de 2017. Aprova a Política Nacional de Atenção Básica estabelecendo a revisão de diretrizes para a organização da Atenção Básica no âmbito do Sistema Único de Saúde (SUS). Diário Oficial da União 2017; 22 de setembro.

15. Morosini MVGC, Fonseca AF. Reviewing the Brazilian National Primary Healthcare Policy at such a time? Cad Saúde Pública 2017;33(1):e00206316. https://doi.org/10.1590/0102-311x00206316

16. Stuckler D, Basu S. A economia desumana: porque mata a austeridade. Lisboa: Editorial Bizâncio; 2014. 302 p.

17. Castro MC, Massuda A, Almeida G, Menezes-Filho NA, Andrade MV, Noronha KVMS, et al. Brazil's unified health system: the first 30 years and prospects for the future. Lancet Public Health 2019; 394(10195):345-356. https://doi.org/10.1016/S0140-6736(19)31243-7

18. Arantes LJ, Shimizu HE, Merchán-Hamann E. The benefits and challenges of the Family Health Strategy in Brazilian Primary Health care: a literature review. Cienc Saude Colet. 2016;21(5):1499-509. https://doi.org/10.1590/1413-81232015215.19602015

19. Menezes ELC, Scherer MDA, Verdi MI, Pires DP. Manners of producing care and universality of access in primary health care. Saúde Soc. 2017;26(4):888-903. https://doi.org/10.1590/S0104-12902017170497

20. Santos DS, Mishima SM, Merhy EE. Processo de trabalho na Estratégia de Saúde da Família: potencialidades da subjetividade do cuidado para reconfiguração do modelo de atenção. Cienc Saude Colet. 2018;23(3):861-70. https://doi.org/10.1590/1413-81232018233.03102016

21. Arksey H, O'Malley L. Scoping studies: towards a methodological framework. Int J Soc Res Methodol. 2005;8(1):19-32. https://doi. org/10.1080/1364557032000119616

22. The Joanna Briggs Institute. Reviewers' Manual 2015. Methodology for JBI Scoping Reviews. Austrália: Joanna Briggs Inst [Internet] 2015 [cited $2020 \mathrm{Jul}$ 29]. Available from: https://nursing.lsuhsc.edu/JBI/docs/ReviewersManuals/Scoping-.pdf

23. Munn Z, Peters MDJ, Stern C, Tufanaru C, McArthur A, Aromataris E. Systematic review or scoping review? guidance for authors when choosing between a systematic or scoping review approach. BMC Med Res Methodol. 2018;18(1):143. https://doi.org/10.1186/ s12874-018-0611-x

24. Rodrigues MP, Lima KC, Roncalli AG. A representação social do cuidado no programa saúde da família na cidade de Natal. Cienc Saude Colet [Internet] 2008 [cited 2020 Jul 21];13(1):71-82. Available from: https://scielosp.org/pdf/csc/2008.v13n1/71-82/pt

25. Barros DM, Sá MC. O processo de trabalho em saúde e a produção do cuidado em uma unidade de saúde da família: limites ao acolhimento e reflexos no serviço de emergência. Cienc Saude Colet. [Internet] 2010 [cited 2020 Jul 21];15(5):2473-82. Available from: https://www.scielo. $\mathrm{br} / \mathrm{pdf} / \mathrm{csc} / \mathrm{v} 15 \mathrm{n} 5 / \mathrm{v} 15 \mathrm{n} 5 \mathrm{a} 22 . \mathrm{pdf}$

26. Franco TB, Koifman L. Produção do cuidado e produção pedagógica no planejamento participativo: uma interlocução com a Educação Permanente em Saúde. Interface Comum Saude Educ 2010;14(34):673-81. https://doi.org/10.1590/S1414-32832010005000016

27. Albuquerque RA, Jorge MSB, Franco TB, Quinderé PHD. Production of comprehensive prenatal care: a pregnant woman's route at a primary family healthcare unit. Interface Comum Saude Educ. 2011;15(38):677-686. doi: 10.1590/S1414-32832011005000041.

28. Baduy RS, Feuerwerker LCM, Zucoli M, Borian JT. A regulação assistencial e a produção do cuidado: um arranjo potente para qualificar a atenção. Cad Saude Publica 2011; 27(2):295-304. https://doi.org/10.1590/S0102-311X2011000200011

29. Nery AA, Carvalho CGR, Santos FPA, Nascimento MS, Rodrigues VP. Saúde da família: visão dos usuários. Rev Enferm UERJ. 2011;19(3):397-402. 
30. Vieira-dos-Santos IMV, Santos AM. Acolhimento no Programa Saúde da Família: revisão das abordagens em periódicos brasileiros. Rev Salud Publica (Bogota) [Internet] 2011 [cited Jul 21] 13(4):703-16. Available from: http://www.scielo.org.co/pdf/rsap/v13n4/v13n4a15.pdf

31. Rodrigues ES, Moreira MIB. A interlocução da saúde mental com atenção básica no município de Vitoria/ES. Saúde Soc. 2012;21(3):599-611. https://doi.org/10.1590/S0104-12902012000300007

32. Amorim ACCLA, Assis MMA, Santos AM. Vínculo e responsabilização como dispositivos para produção do cuidado na Estratégia Saúde da Família. Rev Baiana Saude Publica 2014;38(3):539-54. https://doi.org/10.5327/Z0100-0233-2014380300004

33. Cecílio LCO, Carapinheiro G, Andreazza R, Souza ALM, Andrade MGG, Santiago SM, et al. O agir leigo e o cuidado em saúde: a produção de mapas de cuidado. Cad Saude Publica. 2014;30(7):1502-14. https://doi.org/10.1590/0102-311X00055913

34. Souza MC, Araújo TM, Andrade FA, França AJ, Souza JN. Necessidades de saúde e produção do cuidado em uma unidade de saúde em um município do nordeste, Brasil. O Mundo da Saúde [Internet]. 2014 [cited 2020 Jul 29];38(2):139-148. Available from: http://www.saocamilosp.br/pdf/mundo_saude/155562/A02.pdf

35. Jorge MSB, Diniz AM, Lima LL, Penha JC. Matrix support, individual therapeutic project and production in mental health care. Texto Contexto Enferm. 2015;24(1):112-20. https://doi.org/10.1590/0104-07072015002430013

36. Machado SS, Mattos RJB. Apoio institucional na atenção básica: a experiência no município de Salvador - BA. Rev Baiana Saude Publica. 2015;39(1):139-149. https://doi.org/10.5327/Z0100-0233-2015390100012

37. Matuda CG, Pinto NRS, Martins CL, Frazão P. Colaboração interprofissional na Estratégia Saúde da Família: implicações para a produção do cuidado e a gestão do trabalho. Cienc Saude Colet. 2015;20(8):2511-21. https://doi.org/10.1590/1413-81232015208.11652014

38. Mendes VM, Carvalho YM. Sem começo e sem fim... com as práticas corporais e a Clínica Ampliada. Interface Comum Saude Educ. 2015;19(54):603-13. https://doi.org/10.1590/1807-57622014.0718

39. Silva TF, Romano VF. Sobre o acolhimento: discurso e prática em unidades básicas de saúde do município do Rio de Janeiro. Saúde Debate. 2015;39(105):363-74. https://doi.org/10.1590/0103-110420151050002005

40. Baduy RS, Kulpa S, Tallemberg C, Seixas CT, Cruz KT, Slomp-Jr H, et al. Mas ele não adere! - o desafio de acolher o outro que é complexo para mim. In: Merhy EE, Baduy RS, Seixas CT, Almeida DES, Slomp-Jr H, (Orgs.). Avaliação compartilhada do cuidado em saúde: surpreendendo o instituído nas redes. Rio de Janeiro: Hexis Editora; 2016. p.220-227.

41. Bertussi DC, Feuerwerker LCM, Freire MP, Louvison MCP. Arranjos regulatórios como dispositivos para o cuidado compartilhado em saúde. In: Feuerwerker LCM, Bertussi DC, Merhy EE. Avaliação compartilhada do cuidado em saúde: surpreendendo o instituído nas redes. Rio de Janeiro: Hexis Editora; 2016. p.354-64.

42. Oliveira LA, Cecílio LCO, Andreazza R, Araújo EC. Processos microrregulatórios em uma unidade básica de saúde e a produção do cuidado. Saúde Debate. 2016;40(109):8-21. https://doi.org/10.1590/0103-1104201610901

43. Gurgel ALLG, Jorge MSB, Caminha ECCR, Maia-Neto JP, Vasconcelos MGF. Cuidado em saúde mental na Estratégia Saúde da Família: a experiência do apoio matricial. Rev Enferm UERJ. 2017;25:e7101. https://doi.org/10.12957/reuerj.2017.7101

44. Maximino VS, Liberman F, Frutuoso MF, Mendes R. Profissionais como produtores de redes: tramas e conexões no cuidado em saúde. Saúde Soc. 2017;26(2):435-447. https://doi.org/10.1590/s0104-12902017170017

45. Rios MO, Nascimento MAA. Production of care for resolubility of the Family Health Strategy: knowledge and dilemmas. Rev Enferm UFPE [Internet]. 2017 [cited 2020 Aug 3];11(Suppl 9):3542-50. Available from: https://periodicos.ufpe.br/revistas/revistaenfermagem/article/ view/234484/27678

46. Graff VA, Toassi RFC. Produção do cuidado em saúde com foco na clínica ampliada: um debate necessário na formação em Odontologia. Rev ABENO [Internet] 2017 [cited 2020 Aug 3];17(4):63-72. Available from: https://revabeno.emnuvens.com.br/revabeno/article/view/516

47. Agonigi RC, Carvalho SM, Freire MAM, Gonçalves LF. The production of care in the routine of Family Health Teams. Rev Bras Enferm. 2018;71(Suppl 6):2659-65. https://doi.org/10.1590/0034-7167-2017-0595

48. Fonsêca GS, Pires FS, Junqueira SR, Souza CR, Botazzo C. Redesenhando caminhos na direção da clínica ampliada de saúde bucal. Saúde Soc. 2018;27(4):1174-85. https://doi.org/10.1590/s0104-12902018180117

49. Graff VA, Toassi RFC. Clínica em saúde bucal como espaço de produção de diálogo, vínculo e subjetividades entre usuários e cirurgiõesdentistas da Atenção Primária à Saúde. Physis. 2018;28(3):e280313. https://doi.org/10.1590/s0103-73312018280313

50. Silva TF, David HMSL, Caldas CP, Martins EL, Ferreira SR. O acolhimento como estratégia de vigilância em saúde para produção do cuidado: uma reflexão epistemológica. Saúde Debate 2018;42(Esp.4):249-60. https://doi.org/10.1590/0103-11042018s420 